\title{
Farklı Seyreltik Sodyum Hidroksit Ön İşlem Metotlarının Kargı Kamışı (Arundo donax L.) Bitkisinden Fermente Olabilir Şeker ve Etanol Üretimine Etkileri
}

\begin{abstract}
ÖZ
Recep İrfan NAZLI ${ }^{1}$

Bu çalışma 5 farklı seyreltik sodyum hidroksit $(\mathrm{NaOH})$ ön işlem metodunun $(\% 1.0,1.5,2.0,2.5$ ve 3.0) kargı kamışı bitkisinden biyoetanol üretimine etkilerini araştırmak amacıyla yürütülmüştür. Ön işlem metotları otoklav koşullarında $121^{\circ} \mathrm{C}$ 'de ve 30 dakika süreyle yürütülmüştür. Araştırmada en yüksek indirgen şeker verimi \% $2.5 \mathrm{NaOH}$ ön işlem metodundan elde edilmesine karşın, yüksek katı veriminden dolayı en yüksek teoriksel etanol verimi $\% 1.0 \mathrm{NaOH}$ ön işlem metodundan elde edilmiştir. Bu sonuçlar, araştırmada test edilen ön işlem metotları içerisinde \% $1.0 \mathrm{NaOH}$ ön işlem metodunun kargı kamışı bitkisinden sürdürülebilir bir biyoetanol üretimi gerçekleştirmek için öncelikli olarak tercih edilebileceğini göstermektedir.
\end{abstract}

Anahtar Kelimeler: Sodyum hidroksit, ön işlem, kargı kamışı, etanol, şeker

\section{The Effects of Different Dilute Sodium Hydroxide Pretreatment Methods on Fermentable Sugar and Ethanol Production from Giant Reed (Arundo donax L.)}

\begin{abstract}
This study was conducted to investigate the effects of five different dilute sodium hydroxide $(\mathrm{NaOH})$ pretreatment methods $(\% 1.0,1.5,2.0,2.5$ ve 3.0) on bioethanol production from giant reed. Pretreatments were performed in an autoclave at $121{ }^{\circ} \mathrm{C}$ for $30 \mathrm{~min}$. Despite the highest reducing sugar yield were obtained from $2.5 \% \mathrm{NaOH}$ pretreatment method, $1.0 \% \mathrm{NaOH}$ pretreatment method achieved the highest theoretical ethanol yield. These results shows that $1.0 \% \mathrm{NaOH}$ pretreatment method can be preferred primarily to achieve a sustainable bioethanol production from giant reed, among the pretreatment methods tested in the study.
\end{abstract}

Keywords: Sodium hydroxide, pretreatment, giant reed, ethanol, sugar

ORCID ID (Yazar sirasına göre)

0000-0002-6416-6603

Yayın Kuruluna Geliş Tarihi: 24.03.2021

Kabul Tarihi: 17.04.2021

${ }^{1}$ Çukurova Üniversitesi, Ziraat Fakültesi, Tarla Bitkileri Bölümü, Sarıçam, Adana, Türkiye

E-posta: inazli@cu.edu.tr 


\section{Farklı Seyreltik Sodyum Hidroksit Ön İşlem Metotlarının Kargı Kamışı (Arundo donax L.) Bitkisinden Fermente Olabilir Şeker ve Etanol Üretimine Etkileri}

\section{Giriș}

Fosil yakıt rezervlerinin giderek azalması ve bu yakıtların yoğun kullanımından kaynaklanan sera gazı salınımlarının küresel iklim değişikliğine neden olması 21 . yüzyılda biyoyakıtlar gibi çevre dostu ve yenilenebilir enerji kaynaklarına olan ilginin tekrar artmasına yol açmıştır (Nazlı, 2017). Bu bağlamda, yenilenebilir enerji kaynaklarından birisi olan biyoetanolün ulaşımda benzine alternatif olarak kullanılmasi petrole olan bağımlılı̆̆ ve sera gazı salınımlarını azaltmaktadır (Khullar ve ark., 2013). Biyoetanol, günümüzün küresel enerji krizi ve kötüye giden çevre kalitesi ile mücadelede umut verici bir geleceğe sahip olan yenilenebilir ve sürdürülebilir bir sıvı biyoyakıttır (Aditiya ve ark., 2016).

Biyoetanol günümüzde küresel taşımacılık sektöründe en çok tüketilen biyoyakıt türü olmakla birlikte, genellikle benzinle harmanlanarak kullanılmaktadır (Nazlı, 2020). Günümüzde küresel biyoetanol üretimi için geçerli olan mevcut endüstriyel süreçlerde hammadde olarak çoğunlukla şeker kamışı ve mısır gibi şeker veya nişasta bazlı bitkiler kullanılmaktadır. Fakat bu bitkilerin gıda dışı kullanımları, insanların açlık ve yetersiz beslenmeden muzdarip olduğu bir dünyada etik sorunları da beraberinde getirmektedir (Pesce ve ark., 2020). Ayrica bu durum gida fiyatlarında ciddi bir artışa neden olmakla birlikte insanların kaliteli ve güvenilir gıdaya ulaşımını da zorlaştırmaktadır. $\mathrm{Bu}$ nedenle küresel biyoetanol üretiminde gida hammaddeleri yerine, gida ve yakıt üretimi arasında rekabet oluşturmayan alternatif kaynakların kullanılması sürdürülebilir gıda güvenliği açısından hayati bir önem taşımaktadır (Kärcher ve ark., 2015). Bu bağlamda, 2. nesil olarak da adlandırılan ve genellikle tarımsal atıklar (tahıl samanı, yerfistığ1 kabuğu vb.,), çok yıllık enerji bitkileri (miskantus, dallı darı, kargı kamışı vb.,) ve odunsu bitkiler gibi yüksek miktarda lignoselülozik materyal içeren biyokütlelerden elde edilen lignoselüozik biyoetanol üretimi en sürdürülebilir ve çevre dostu biyoetanol üretim yöntemi olarak kabul edilmektedir. Ayrıca bu yöntem sera gazı salınımlarında \%85'e kadar azalmaya yol açarak küresel iklim değişikliği ile mücadelede önemli bir fayda sağlamaktadır (Keshav ve ark., 2018).

Lignoselülozik biyokütlenin kuru ağırlığının yaklaşık \% 90'ı selüloz, hemiselüloz ve lignin olarak bilinen hücre duvarı bileşenlerinden oluşmaktadır (Haq ve ark., 2016). Lignoselülozik biyokütleden etanol üretebilmek için selüloz ve hemiselülozun fermantasyon aşamasından önce fermente olabilir şeker formlarına (glikoz, ksiloz, arabionoz, galaktoz vb.,) enzimatik veya asit hidroliz yoluyla dönüştürülmesi gerekmektedir (Aita ve ark., 2011). Buna karşın, ligninhemiselüloz kompleksinin varlı̆̆ 1 , selülozun kristal yapısı ve ligninin karmaşık yapısından dolayı yapısal bozulmalara karşı oldukça dirençli olması biyokütleyi enzimatik ayrışmaya karşı oldukça dirençli hale getirerek fermente olabilir şeker üretiminde önemli bir düşüşe neden olmaktadır (Aita ve ark., 2011; Cao ve ark., 2012; Lainez ve ark., 2018). Ayrica ligninin karbonhidrat polimerlerine (selüloz ve hemiselüloz) hidrojen ve bazı kovelent bağlarla sıkıca bağlanmış olmasından dolayı enzimatik hidroliz esnasında enzimlerin selüloz ve hemiselüloze ulaşmasını engelleyen fiziksel bir bariyer oluşturmaktadır (Qing ve Wyman, 2011; Barcelos ve ark., 2013). $\mathrm{Bu}$ nedenle, lignoselülozik biyokütlenin enzimatik sindirilebilirliğini artırmak için hidroliz işleminden hemen önce ligninin selüloz ve hemiselülozle ilişkisinin kesilmesi, selülozun kristallik derecesinin azaltılması ve hücre duvarının dirençli yapısını tamamen parçalanarak biyokütle gözenekliliğinin artırılması için bir ön işlem adımı mutlak suretle gerekmektedir (Santos ve ark., 2018; Nishimura ve ark., 2018). Bugüne kadar mekanik, fiziko-kimyasal, kimyasal, termal, biyolojik ve bunların kombinasyonları da dahil olmak üzere bir çok ön işlem metodu geliştirilmiştir (Aita ve ark., 2011). Bunlar içerisinde, genellikle seyreltik asit (sülfürik asit, hidroklorik asit) ve alkali (sodyum hidroksit, kireç, amonyak) uygulamaları ile yapılan kimyasal ön işlem yöntemleri ekonomik ve kolay uygulanabilir olmalarından ötürü çok fazla tercih edilmektedirler (Pandey ve ark., 2000; Barcelos ve ark., 2013). Seyreltik sodyum hidroksit $(\mathrm{NaOH})$ ön işlemi selülozün iç yüzey alanını arttırmakta ve polimerizasyon ve kristallik derecesini düşürerek 


\section{Farklı Seyreltik Sodyum Hidroksit Ön İşlem Metotlarının Kargı Kamışı (Arundo donax L.) Bitkisinden Fermente Olabilir Şeker ve Etanol Üretimine Etkileri}

lignin yapısının bozulmasına neden olmaktadır (Barcelos ve ark., 2013). Bu durum lignin miktarının büyük oranda azalmasını ve lignin bariyerinin ortadan kalkmasını sağlayarak hidroliz enzimlerinin selüloz ve hemiselüloze daha kolay erişebilmelerine imkan tanır (Xu ve ark., 2010). İlaveten, seyreltik asit ön işlemi ile kıyaslandığında, seyreltik $\mathrm{NaOH}$ ön işleminde fermantasyon mikroorganizmaları üzerinde toksik etkiye neden olan inhbitör bileşik (furfural, HMF, asetik asit vb.,) oluşumu genellikle daha düşük seviyede kalmaktadır (Chen ve ark., 2012; Menezes ve ark., 2014).

Karg1 kamış1 (Arundo donax L.) buğdaygiller (Poacea) familyasına ait çok yıllık bir sıcak mevsim bitkisidir. Asya orjinli bir bitki olmasına karşın Akdeniz iklim kuşağı altındaki ülkelerin de doğal bir türü olduğu düşünülmektedir (Rossa ve ark., 1998; Boose ve Holt, 1999). Ülkemizde Ege ve Akdeniz Bölgesi'nde, özellikle sahil kuşağında bataklık, dere, ırmak, göl vb. su kaynaklarının olduğu yerlerde doğal vejetasyonda yoğunlukla bulunmakla birlikte Çorum'un Karg1 ilçesinde doğal olarak yayılış göstermektedir (Kuşvuran ve ark., 2019). Bir $\mathrm{C}_{3}$ bitkisi olan kargı kamışı yüksek biyokütle verimi ve adaptasyon kabiliyeti, hızlı büyüme özelliği ve düşük girdi gereksinimi nedeniyle özellikle Akdeniz ülkelerinde lignoselülozik biyoetanol üretiminde kullanılabilecek umut verici bir hammadde olarak kabul edilmektedir (Lemoes e Silva ve ark., 2018; Nazlı ve ark., 2018). Bu çalışma farklı seyreltik $\mathrm{NaOH}$ ön işlem uygulamalarının kargı kamışı bitkisinin fermente olabilir şeker ve etanol verimlerine etkilerini araştırmak amacıyla yürütülmüştür.

\section{Materyal ve Yöntem}

Materyal: Araştırmada hammadde olarak kullanılan kargı kamışı biyokütlesi Ç.Ü. Ziraat Fakültesi Tarla Bitkileri Bölümü Araştırma ve Uygulama Alanı'nda bulunan tarla denemesinden 2019 yılı Kasım ayı içerisinde hasat edilmiştir. Hasattan hemen sonra 1000 gr ağırlığındaki biyokütle örneği $105{ }^{\circ} \mathrm{C}$ 'de ağırlığı sabit kalıncaya kadar kurutma dolabında bekletilmiş, ardından ön işlem uygulamalarında kullanılmak üzere $1 \mathrm{~mm}$ çapında eleklere sahip bitki öğütme değirmeninde ögütülmüştür.

Yöntem: Seyreltik $\mathrm{NaOH}$ çözeltilerini hazırlamak için ilk olarak $100 \mathrm{ml}$ saf suya \% 1.0, 1.5, 2.0, 2.5 ve 3.0 konsantrasyonlarında $\mathrm{NaOH}$ eklenmiş ve ardından 10 gr ağırlığındaki kuru biyokütle örnekleri hazırlanan bu çözeltilere karıștırılmıștır. Elde edilen karışımlar otoklavda $121{ }^{\circ} \mathrm{C}$ 'de 30 dakika süreyle bekletilerek ön işlem uygulamalarını tamamlanmıştır. Otoklavdan çıkarılan örnekler oda sicaklığına kadar soğutulduktan sonra katı biyokütle sıvı kısımdan filtreleme yöntemi ile ayrıştırılmış ve saf su ile $\mathrm{pH}$ nötr oluncaya kadar yıkanmıştır. Son olarak elde edilen biyokütle örnekleri $105^{\circ} \mathrm{C}$ 'de ağırlığı sabit kalıncaya kadar etüvde kurutulmuştur (Cao ve ark., 2012).

Hammadde ve ön işlem uygulamalarından elde edilen örneklerin hücre duvarı kompozisyonu (lignin, selüloz ve hemiselüloz) Van Soest (1963) yöntemine uygun olarak belirlenmiştir. Ayrıca, katı verimi ve lignin giderimi aşağıdaki eşitliklere uygun olarak hesaplanmıştır (Yan ve ark., 2020):

Katı verimi (\%): [Ön işlenmiş biyokütle (g) / Hammadde (g)] x 100

Lignin giderimi (\%): 100 - [Ön işlenmiş biyokütle (g) $x$ Ön işlemeden sonraki lignin (\%)] / [Hammadde (g) x Hammaddedeki lignin (\%)] x 100

2 gr ağırlığındaki kurutulmuş ön işlem ve ön işleme tabii tutulmamış kontrol örnekleri $100 \mathrm{ml}$ sodyum sitrat tamponu (50 mM, pH: 4.8) içerisine karıştırılmış ve ardından $\mathrm{pH}$ 'ın tekrar 4.8'e düşürülmesi için karışım içerisine birkaç damla hidroklorik asit $(\mathrm{HCl})$ damlatılmıştır (Cao ve ark., 2012). Selüloz ve hemiselülozun hidrolizi için "Accellerase 1500" enzimi $0.24 \mathrm{ml} / \mathrm{g}$ biyokütle dozunda kullanılmıştır (Choudhary ve ark., 2012). Son olarak, mikrobiyal kirliliği önlemek için çözelti içerisine \% 0.02 konsantrasyonunda sodyum azit eklenmiştir (Niemi ve ark., 2017). Enzim yüklemesinin ardından, hazırlanan örnekler $50^{\circ} \mathrm{C}$ 'de $150 \mathrm{rpm}$ çalkalama hızında 72 saat süreyle su banyosunda inkübe edilerek enzimatik hidroliz tamamlanmıştır. Enzimatik hidroliz sonrası süzme işlemi yapılarak çözelti katı 


\section{Farklı Seyreltik Sodyum Hidroksit Ön İşlem Metotlarının Kargı Kamışı (Arundo donax L.) Bitkisinden Fermente Olabilir Şeker ve Etanol Üretimine Etkileri}

haldeki biyokütle atıklarından arındırılmıștır. İndirgen şeker analizleri için her bir örnekten yaklaşık $20 \mathrm{ml}$ örnek alınarak $-20{ }^{\circ} \mathrm{C}$ 'de muhafaza edilmiştir. Toplam indirgen şeker miktarı (mg/g) 3,5-dinitrosalisilik asit (DNS) yöntemine göre belirlenmiştir (Miller, 1959). Son olarak, enzimatik hidroliz ve teorik etanol verimleri aşağıdaki eşitliklere uygun olarak hesaplanmıştır (Chen ve ark., 2007; Pesce ve ark., 2020).

Enzimatik hidroliz verimi (\%): [İndirgen şeker verimi $(\mathrm{mg} / \mathrm{g}) \times 0.9$ ] / [Toplam polisakkarit (mg)] x 100

Teorik Etanol Verimi (mg/g hammadde): Kat1 verimi $(\%) \times$ İndirgen şeker verimi $(\mathrm{mg} / \mathrm{g}) \times$ 0.511

0.9 ve 0.511 sirasıyla şekerin polisakkaritlere ve etanole dönüşüm faktörlerini ifade etmektedir.

İstatistiksel Analiz: Araştırmaya konu olan deneysel çalışma tesadüf parselleri deneme desenine göre 3 tekrarlamalı olarak yürütülmüş̧ür. Araştırmadan elde edilen veriler JMP 7.0 istatistik paket programı kullanılarak varyans analizine tabii tutulmuş ve ortalamalar arası karşılaştırmalarda EGF testi kullanılmıştır.

\section{Bulgular ve Tartışma}

Araştırmada incelenen tüm parametreler ön işlem metotlarından önemli düzeyde etkilenmiştir.

Ön işlem uygulamaları esnasında lignin, selüloz ve hemiselülozün bozulmasından kaynaklı olarak bir miktar kuru madde kayb1 meydana gelmektedir. Katı verimi toplam biyokütleden kuru madde kayıplarının çıkarılmasıyla elde edilen değeri ifade etmektedir. Araştırmada farklı dozlarda $\mathrm{NaOH}$ ön işlem metotlarından elde edilen kat1 verimleri \%44.6-64.0 arasinda değişmiş olup, en yüksek değer \%1.0, en düşük değer ise \%3.0 NaOH ön işlem metodundan elde edilmiştir (Çizelge 1). $\mathrm{NaOH}$ dozlarındaki her bir artış katı veriminde önemli düzeyde azalmaya neden olmuştur. Benzer olarak, Wang ve ark. (2010) köpek dişi ayrığı, Xu ve Cheng, (2011) dallı darı, Jiang ve ark., (2016) ise kargı kamışı bitkisinde artan $\mathrm{NaOH}$ ön işlem dozlarının katı verimini önemli düzeyde azalttı̆̆ını bildirmişlerdir.

Çizelge 1. Farklı dozlarda $\mathrm{NaOH}$ ön işlem metotlarının kargı kamışı bitkisinin biyokütle kompozisyonuna etkisi

\begin{tabular}{llllll}
\hline $\begin{array}{l}\text { NaOH } \\
\text { Dozlar1 } \\
(\%)\end{array}$ & $\begin{array}{l}\text { Kat1 verimi } \\
(\%)\end{array}$ & $\begin{array}{l}\text { Selüloz } \\
(\%)\end{array}$ & $\begin{array}{l}\text { Hemiselüloz } \\
(\%)\end{array}$ & $\begin{array}{l}\text { Lignin } \\
(\%)\end{array}$ & $\begin{array}{l}\text { Lignin } \\
\text { giderimi } \\
(\%)\end{array}$ \\
\hline Kontrol & - & $41.0 \mathrm{E}$ & $20.2 \mathrm{~A}$ & $10.27 \mathrm{~A}$ & - \\
1.0 & $64.0 \mathrm{~A}$ & $65.5 \mathrm{D}$ & $13.0 \mathrm{~B}$ & $7.63 \mathrm{~B}$ & $52.4 \mathrm{E}$ \\
1.5 & $55.7 \mathrm{~B}$ & $67.6 \mathrm{C}$ & $10.7 \mathrm{~B}$ & $7.14 \mathrm{C}$ & $61.3 \mathrm{D}$ \\
2.0 & $50.3 \mathrm{C}$ & $69.8 \mathrm{~B}$ & $10.6 \mathrm{~B}$ & $6.4 \mathrm{D}$ & $68.6 \mathrm{C}$ \\
2.5 & $46.2 \mathrm{D}$ & $72.1 \mathrm{~A}$ & $10.3 \mathrm{~B}$ & $5.3 \mathrm{E}$ & $76.3 \mathrm{~B}$ \\
3.0 & $44.6 \mathrm{E}$ & $72.9 \mathrm{~A}$ & $9.9 \mathrm{~B}$ & $4.7 \mathrm{~F}$ & $79.6 \mathrm{~A}$ \\
Ortalama & 52.16 & 64.8 & 12.5 & 6.9 & 67.6 \\
EGF $(0.05)$ & 1.46 & 2.02 & 4.01 & 0.45 & 2.40 \\
\hline
\end{tabular}

Araştırmada farklı dozlarda $\mathrm{NaOH}$ ön işlem metotları ve kontrol uygulamasindan elde edilen selüloz oranı değerleri \%41.0-72.9 arasında değişmiştir (Çizelge 1). En yüksek değer \%3.0 NaOH ön işlem metodundan edilirken, bunu önemsiz farkla \%2.5 NaOH ön işlem metodu izlemiştir. En düşük değer ise kontrol uygulamasından elde edilmiştir. Araştırmada uygulanan tüm ön işlem metotları kontrole kıyasla selüloz oranını önemli düzeyde artırmış ve bu artışlar yaklaşık olarak \%60-78 arasında değişmiştir. Uygun koşullarda yapılan 


\section{Farklı Seyreltik Sodyum Hidroksit Ön İşlem Metotlarının Kargı Kamışı (Arundo donax L.) Bitkisinden Fermente Olabilir Şeker ve Etanol Üretimine Etkileri}

seyreltik $\mathrm{NaOH}$ ön işlem uygulamalarında biyokütledeki selülozun glikoz gibi monosakkaritlere hidrolizi çok sinırlı seviyelerde kalmakta fakat lignin büyük oranda, hemiselülozun ise önemli bir kısmı daha küçük ve basit yapılı moleküllere ayrışmaktadır (Barcelos ve ark., 2013). Sonuç olarak, aslında ön işleme uğramış biyokütledeki selüloz miktarı hammadde ile hemen hemen aynı olmasına rağmen, lignin ve hemiselüloz miktarında meydana gelen azalmalardan ötürü ön işleme uğramış biyokütledeki selüloz oranı hammaddedekine kıyasla önemli düzeyde yüksek olmaktadır. Araştırmadan elde ettiğimiz sonuçlara benzer olarak, önceki çalışmalar seyreltik $\mathrm{NaOH}$ ön işlem metodunun tatlı sorgum bagası (Cao ve ark., 2012), fil otu (Eliana ve ark., 2014), karg1 kamış1 (Lemons e Silva ve ark., 2015) ve miskantus (Michalska ve ark., 2015) bitkilerinde selüloz oranını önemli düzeyde arttırdığını bildirmişlerdir.

Araștırmada farklı dozlarda $\mathrm{NaOH}$ ön işlem metotları ve kontrol uygulamasindan elde edilen hemiselüloz oranı değerleri \%9.9-20.2 arasında değişmiştir (Çizelge 1). En yüksek değer kontrol uygulamasından, en düşük değer ise \%3.0 $\mathrm{NaOH}$ ön işlem metodundan elde edilmiştir. Araştırmada uygulanan tüm ön işlem metotları kontrole kıyasla hemiselüloz oranını önemli düzeyde azaltmış ve bu azalmalar yaklaşık olarak \%36-51 arasında değişmiştir. Fakat uygulanan $\mathrm{NaOH}$ ön işlem dozları arasında hemiselüloz oranı bakımından istatistiki açıdan önemli düzeyde bir fark meydana gelmemiștir. Seyreltik $\mathrm{NaOH}$ ișlem uygulamaları esnasında biyokütledeki hemiselüloz fraksiyonlarının önemli bir kısmı bir monosakkarit olan ksiloza dönüşmektedir. $\mathrm{Bu}$ durum her ne kadar hidroliz aşamasında üretilebilecek toplam potansiyel şeker verimini düşürse de, aslında lignin-hemiselüloz kompleksinin büyük oranda ortadan kaldırılmasından kaynaklı olarak hidroliz enzimleri selüloza daha rahat ulaşırlar ve sonuç olarak enzimatik sindirilebilirlik artar (Hendricks ve Zeeman 2009; Zhang ve ark., 2010). Araştırmadan elde ettiğimiz sonuçlara benzer olarak, Haque ve ark. (2013) 4 farkl seyreltik $\mathrm{NaOH}$ ön işlem dozunun $(\% 0.75,1.5$,
2.0 ve 2.5 ) miskantus bitkisinin hemiselüloz oranını önemli düzeyde azalttığını ve bu azalmaların \%14-61 arasında değiştiğini bildirmişlerdir.

Araştırmada farklı dozlarda $\mathrm{NaOH}$ ön işlem metotları ve kontrol uygulamasindan elde edilen lignin oranı değerleri \%4.7-10.27 arasında değişmiştir (Çizelge 1). En yüksek değer kontrol uygulamasından, en düşük değer ise hemiselüloz oranında olduğu gibi \%3.0 $\mathrm{NaOH}$ ön ișlem metodundan elde edilmiştir. $\mathrm{NaOH}$ dozlarındaki her bir artışta lignin oranı önemli düzeyde azalmış ve bu azalmalar \%26-54 arasında değişmiştir. Diğer taraftan, araştırmada farklı dozlarda $\mathrm{NaOH}$ ön işlem metotlarından elde edilen lignin giderimi değerleri \%52.4-79.6 arasında değişmiş olup, en yüksek değer $\% 3.0$, en düşük değer ise $\% 1.0$ $\mathrm{NaOH}$ ön işlem metotlarından elde edilmiştir. Lignin oranından farklı olarak, $\mathrm{NaOH}$ dozlarındaki her bir artışta lignin giderimi değerleri önemli düzeyde artmıştır. Bu sonuçlar büyük olasılıkla alkali ön işlem uygulamalarının lignin yapısını bozmaları ve lignin ve polisakkaritler arasındaki hidrojen ve diğer kovalent bağları parçalayarak lignin fraksiyonlarının büyük kısmını biyokütleden uzaklaştırmaları ile ilişkilidir (Si ve ark., 2015; Phitsuwan ve ark., 2016). Araştırmadan elde ettiğimiz sonuçlara benzer olarak, önceki çalışmalarda (Cheng ve ark., 2010; Wang ve ark., 2010; Xu ve ark., 2010; Xu ve Cheng, 2011; Haque ve ark., 2013; Umagiliyage ve ark., 2015; Jung ve ark., 2020) da seyreltik $\mathrm{NaOH}$ ön işlem metodunun farklı bitkilerde lignin oranını önemli düzeyde azalttığını ve buna bağlı olarak artan $\mathrm{NaOH}$ dozların lignin giderimini önemli düzeyde arttırdı ğını bildirilmiştir.

Araştırmada farklı dozlarda $\mathrm{NaOH}$ ön işlem metotları ve kontrol uygulamasindan elde edilen indirgen şeker verimleri 254.9-635.2 mg/g arasında değişmiştir (Şekil 1). En yüksek değer $\% 2.5 \mathrm{NaOH}$ ön işlem metodundan, en düşük değer ise kontrol uygulamasından elde edilmiștir. Araştırmada uygulanan tüm $\mathrm{NaOH}$ ön işlem dozları kontrol uygulamasına göre kargı kamış1 bitkisinden elde edilen indirgen şeker verimini önemli düzeyde arttırmıştır. Bu durum alkali ön işlem uygulamalarının biyokütledeki lignin oranı ve selülozun kristallik derecesini azaltması ile 


\section{Farklı Seyreltik Sodyum Hidroksit Ön İşlem Metotlarının Kargı Kamışı (Arundo donax L.) Bitkisinden Fermente Olabilir Şeker ve Etanol Üretimine Etkileri}

ilişkili olabilir (Hendriks ve Zeeman, 2009; Barcelos ve ark., 2013). Benzer olarak, Wang ve ark., (2012) dallı darı, Jiang ve ark., (2016) karg1 kamış1, Jung ve ark., (2020) ise miskantus bitkisinde farklı dozlarda seyreltik $\mathrm{NaOH}$ ön işlem metotlarının enzimatik hidroliz sonucu elde edilen şeker verimini önemli düzeyde arttırdığını bildirmişlerdir. Buna karşın, \%3.0 NaOH ön işlem metodu tüm uygulamalar arasında istatistiki açıdan en düşük lignin oranı ve en yüksek lignin giderimi sağlamasına rağmen, diğer $\mathrm{NaOH}$ ön işlem metotlarından önemli düzeyde daha düşük indirgen şeker verimine yol açmıştır. Benzer olarak, Wang ve ark. (2010) köpek dişi ayrığ bitkisinde $\% 3.0 \mathrm{NaOH}$ ön işlem metodunun \%1.0 ve $\% 2.0 \mathrm{NaOH}$ ön işlem metotlarından önemli düzeyde daha düşük indirgen şeker verimi sağladığını bildirmişlerdir. Bu sonucun ortaya çıkmasında, artan alkali dozlarının fermente olabilir şeker üretimini düşüren inhibitör bileşik oluşumuna yol açması etkili olmuş olabilir (Kaur ve Phutela, 2016).

Indirgen Şeker Verimi (mg/g)

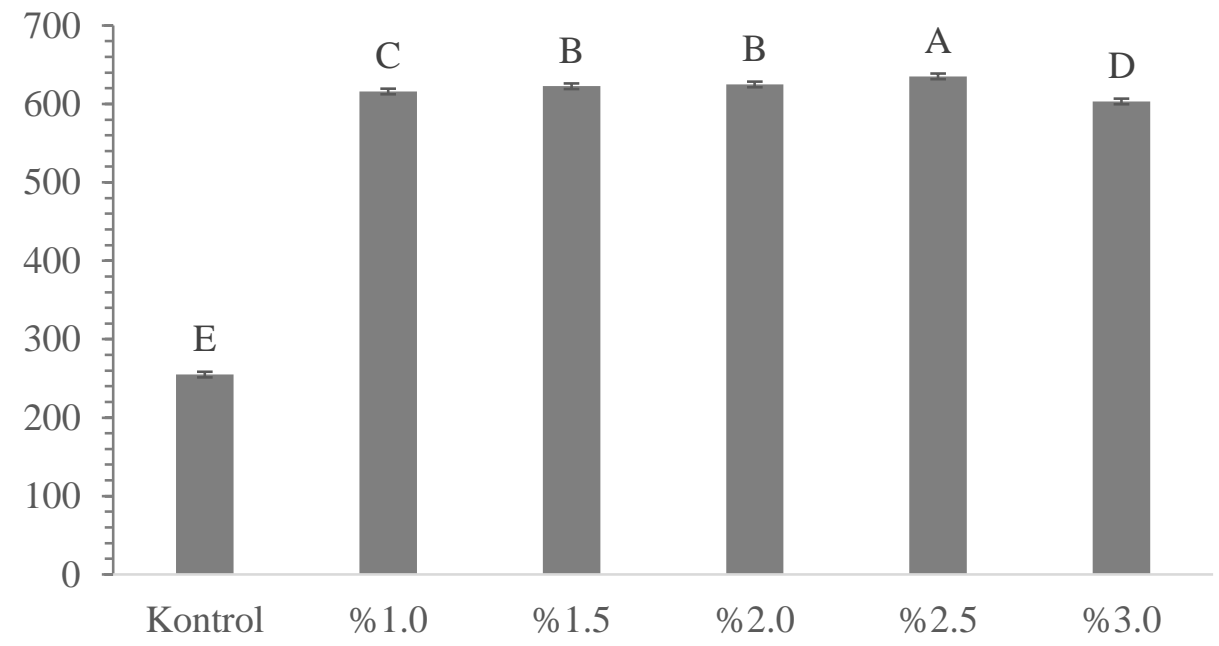

Şekil 1. Farklı dozlarda $\mathrm{NaOH}$ ön işlem metotlarının enzimatik hidroliz sonucu kargı kamış1 bitkisinden elde edilen toplam indirgen şeker verimine etkisi

Araştırmada farklı dozlarda $\mathrm{NaOH}$ ön işlem metotlar1 ve kontrol uygulamasindan elde edilen enzimatik hidroliz verimi değerleri \%37.5-73.5 arasında değişmiştir (Şekil 2). En yüksek değer $\% \quad 1.0 \quad \mathrm{NaOH}$ ön işlem metodundan elde edilmiş olup, bunu önemsiz farkla \% $1.5 \mathrm{NaOH}$ ön işlem metodu izlemiştir. En düşük değer ise kontrol uygulamasından elde edilmiștir. İndirgen șeker verimindeki artışa rağmen, $\mathrm{NaOH}$ dozları artıkça enzimatik hidroliz veriminde azalma eğilimi gözlenmiştir. $\mathrm{Bu}$ durum farklı dozlardaki $\mathrm{NaOH}$ ön işlem uygulamaları sonucu biyokütleki selüloz ve hemiselüloz oranlarında meydana gelen değișikliklerle ilișkili olabilir. Araștırmadan elde ettiğimiz sonuçlardan farklı olarak Jiang ve ark. (2016) karg1 kamış1, Jung ve ark. (2020) ise miskantus bitkilerinde artan seyreltik $\mathrm{NaOH}$ ön işlem dozlarının enzimatik hidroliz verimini önemli düzeyde arttırdığını bildirmişlerdir. 


\title{
Farklı Seyreltik Sodyum Hidroksit Ön İşlem Metotlarının Kargı Kamıșı (Arundo donax L.) Bitkisinden Fermente Olabilir Şeker ve Etanol Üretimine Etkileri
}

\author{
Enzimatik Hidroliz Verimi (\%)
}

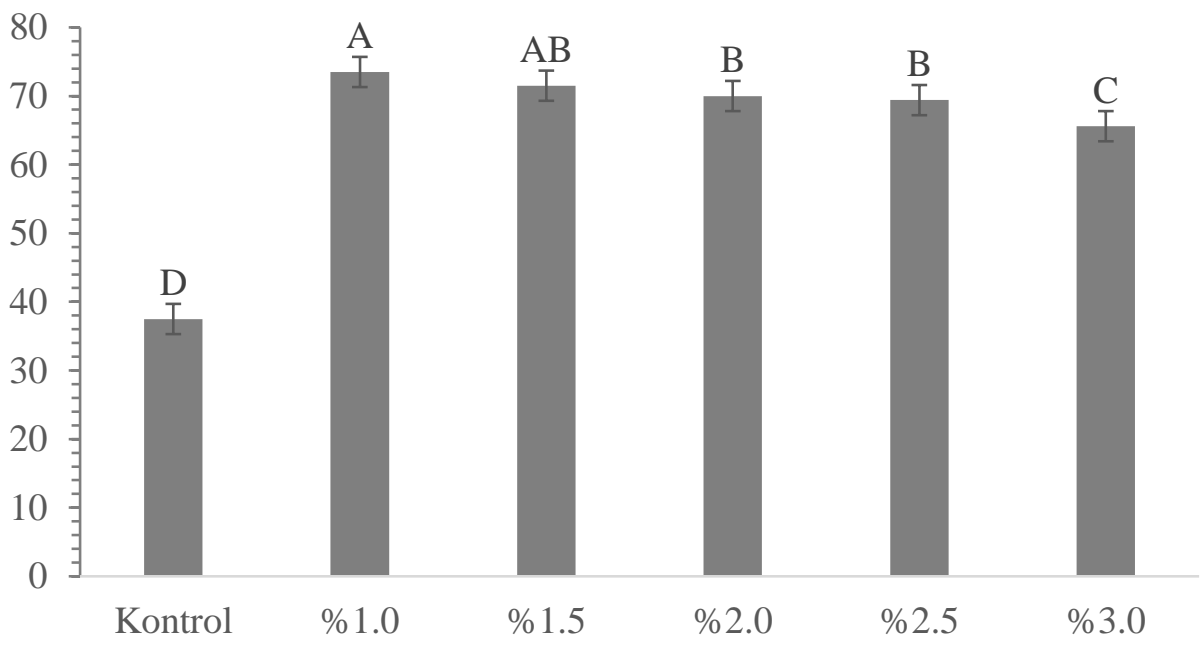

Şekil 2. Farklı dozlarda $\mathrm{NaOH}$ ön işlem metotlarının kargı kamışı bitkisinin enzimatik hidroliz verime etkisi

Araştırmada farklı dozlarda $\mathrm{NaOH}$ ön işlem metotları ve kontrol uygulamasindan elde edilen teoriksel etanol verimi değerleri 130.2 $201.5 \mathrm{mg} / \mathrm{g}$ hammadde arasında değişmiştir (Şekil 3). En yüksek değer enzimatik hidroliz veriminde olduğu gibi \%1.0 NaOH ön işlem metodundan elde edilirken, en düşük değer ise kontrol uygulamasından elde edilmiştir. Araştırmada uygulanan tüm seyreltik $\mathrm{NaOH}$ ön işlem metotları teoriksel etanol verimini önemli düzeyde arttırmış ve bu artışlar yaklaşık olarak \%6-55 arasında değişmiştir. Araştırmadan elde ettiğimiz sonuçlara benzer olarak, Cao ve ark. (2012) seyreltik $\mathrm{NaOH}$ ön işlem metodunun tatlı sorgum bagasından elde edilen etanol verimini kontrol uygulamasına kıyasla önemli düzeyde arttırdığını bildirmişlerdir. Buna karşın, indirgen şeker verimindeki artışa rağmen, $\mathrm{NaOH}$ ön işlem dozlarındaki artış, katı verimindeki azalmadan kaynaklı olarak teoriksel etanol verimini önemli düzeyde azaltmıștır. $\mathrm{Bu}$ durum, ön ișlem uygulamaları esnasinda meydana gelen kuru madde kayıplarının enerji bitkilerinden fermantasyon sonucu elde edilebilecek toplam potansiyel etanol verimini sınırlayan en önemli parametrelerden biri olduğunu ile ilgili görüşleri (Zhu ve ark., 2005; Cao ve ark., 2012) doğrulamaktadır. 


\title{
Farklı Seyreltik Sodyum Hidroksit Ön İşlem Metotlarının Kargı Kamışı (Arundo donax L.) Bitkisinden Fermente Olabilir Şeker ve Etanol Üretimine Etkileri
}

\author{
Teoriksel Etanol Verimi (mg/g hammadde)
}

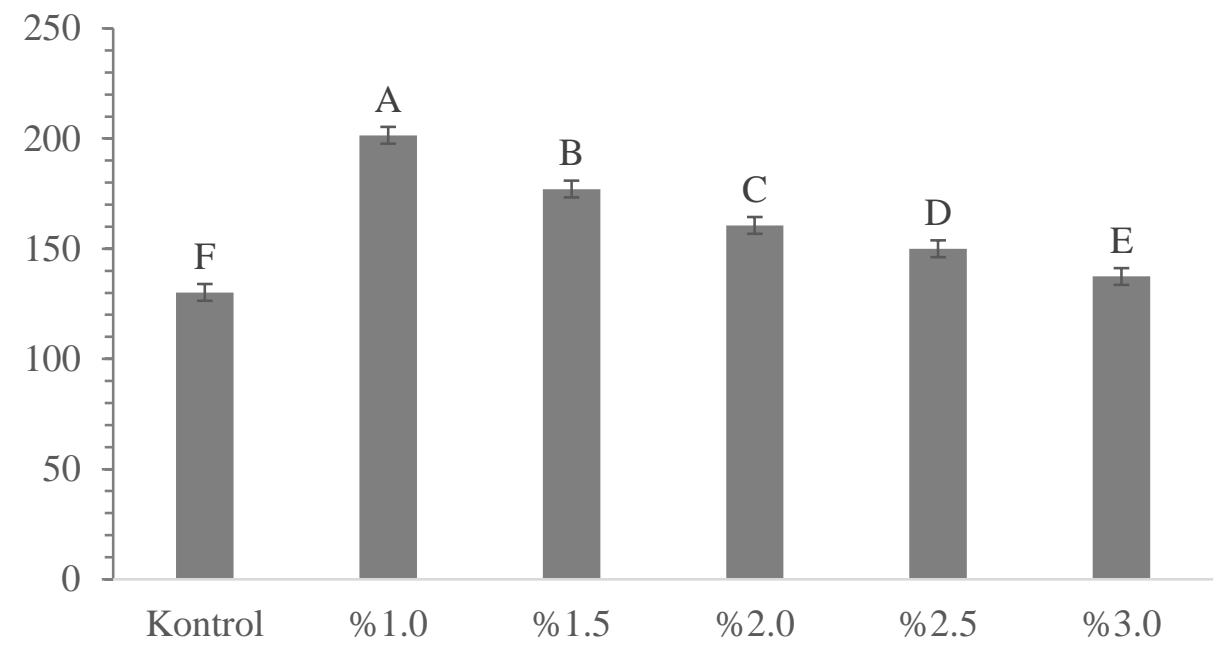

Şekil 3. Farklı dozlarda $\mathrm{NaOH}$ ön işlem metotlarının kargı kamışı bitkisinin teoriksel etanol verime etkisi

\begin{abstract}
Sonuç
Araştırmada en yüksek selüloz ve lignin giderimi ve en düşük lignin oranı $\% 3.0 \mathrm{NaOH}$ ön işlem metodundan, en yüksek indirgen şeker verimi $\% 2.5 \mathrm{NaOH}$ ön işlem metodundan ve en yüksek kat1, enzimatik hidroliz ve teoriksel etanol verimleri ise \%1.0 NaOH ön işlem metodundan elde edilmiştir. Bu sonuçlar, araştırmada test edilen ön işlem metotları içerisinde $\% 1.0 \mathrm{NaOH}$ ön işlem metodunun kargı kamışı bitkisinden sürdürülebilir bir biyoetanol üretimi gerçekleştirmek için öncelikli olarak tercih edilebileceğini göstermektedir.
\end{abstract}

\section{Kaynaklar}

Aditiya, H.B., Mahlia, T.M.I., Chong, W.T., Nur, H., Sebayang, A.H. (2016) Second generation bioethanol production: A critical review. Renewable and sustainable energy reviews 66:631-653.

Aita, G.A., Salvi, D.A., Walker, M.S. (2011) Enzyme hydrolysis and ethanol fermentation of dilute ammonia pretreated energy cane. Bioresource Technology 102:4444-4448.

Barcelos, C.A., Maeda, R.N., Betancur, G.J.V., Pereira, N. (2013) The essentialness of delignification on enzymatic hydrolysis of sugar cane bagasse cellulignin for second generation ethanol production. Waste and Biomass Valorization 4:341-346.

Boose, A.B., Holt, J.S. (1999) Environmental effects on asexual reproduction in Arundo donax. Weed Research, 39:117-27.

Cao, W., Sun, C., Liu, R., Yin, R., Wu, X. (2012) Comparison of the effects of five pretreatment methods on enhancing the enzymatic digestibility and ethanol production from sweet sorghum bagasse. Bioresource Technology 111:215-221.

Chen, B.Y., Chen, S.W., Wang, H.T. (2012) Use of different alkaline pretreatments and enzyme models to improve low-cost cellulosic biomass conversion. Biomass and Bioenergy 39:182-191.

Chen, M., Xia, L., Xue, P. (2007) Enzymatic hydrolysis of corncob and ethanol production from cellulosic hydrolysate. International

Biodeterioration \& Biodegradation 59:8589.

Cheng, Y.S., Zheng, Y., Yu, C.W., Dooley, T.M., Jenkins, B.M., Vander Gheynst, J.S. (2010) Evaluation of high solids alkaline pretreatment of rice straw. Applied 


\section{Farkıı Seyreltik Sodyum Hidroksit Ön İşlem Metotlarının Kargı Kamışı (Arundo donax L.) Bitkisinden Fermente Olabilir Şeker ve Etanol Üretimine Etkileri}

biochemistry

and biotechnology 162:1768-1784.

Choudhary, R., Umagiliyage, A.L., Liang, Y., Siddaramu, T., Haddock, J., Markevicius, G. (2012) Microwave pretreatment for enzymatic saccharification of sweet sorghum bagasse. Biomass and Bioenergy 39:218-226.

Eliana, C., Jorge, R., Juan, P., Luis, R. (2014) Effects of the pretreatment method on enzymatic hydrolysis and ethanol fermentability of the cellulosic fraction from elephant grass. Fuel 118: 41-47.

Haq, F., Ali, H., Shuaib, M., Badshah, M., Hassan, S.W., Munis, M.F.H., Chaudhary, H.J. (2016) Recent progress in bioethanol production from lignocellulosic materials: A review. International Journal of Green Energy 13:1413-1441.

Haque, M.A., Barman, D.N., Kang, T.H., Kim, M.K., Kim, J., Kim, H., Yun, H.D. (2013) Effect of dilute alkali pretreatment on structural features and enhanced enzymatic hydrolysis of Miscanthus sinensis at boiling temperature with low residence time. Biosystems engineering 114:294-305.

Hendricks, A.T.W., Zeeman, G. (2009) Pretreatments to enhance the digestibility of lignocellulosic biomass. Bioresource Technology 100:10-18.

Jiang, D., Ge, X., Zhang, Q., Li, Y. (2016) Comparison of liquid hot water and alkaline pretreatments of giant reed for improved enzymatic digestibility and biogas energy production. Bioresource technology 216:60-68.

Jung, W., Savithri, D., Sharma-Shivappa, R., Kolar, P. (2020) Effect of sodium hydroxide pretreatment on lignin monomeric components of Miscanthus $\times$ giganteus and enzymatic hydrolysis. Waste and Biomass Valorization, 11:5891-5900.

Kärcher, M.A., Iqbal, Y., Lewandowski, I., Senn, T. (2015) Comparing the performance of Miscanthus x giganteus and wheat straw biomass in sulfuric acid based pretreatment. Bioresource technology, 180, 360-364.

Kaur, K., Phutela, U.G. (2016) Enhancement of paddy straw digestibility and biogas production by sodium hydroxidemicrowave pretreatment. Renewable Energy 92:178-184.

Keshav, P.K., Banoth, C., Anthappagudem, A., Linga, V.R., Bhukya, B. (2018) Sequential acid and enzymatic saccharification of steam exploded cotton stalk and subsequent ethanol production using Scheffersomyces stipitis NCIM 3498. Industrial Crops and Products 125:462-467.

Khullar, E., Dien, B.S., Rausch, K.D., Tumbleson, M.E., Singh, V. (2013) Effect of particle size on enzymatic hydrolysis of pretreated Miscanthus. Industrial crops and products 44:11-17.

Kuşvuran, A., Kuşvuran, Ş., Nazlı, R. İ., Tansı, V. (2019) Karg1 Kamışı (Arundo donax L.)'nda Tuz Stresinin Morfolojik ve Fizyolojik Özelliklere Etkisi. Yüzüncü Y1l Üniversitesi Tarım Bilimleri Dergisi, 29:233-241.

Láinez, M., Ruiz, H.A., Castro-Luna, A.A., Martínez-Hernández, S. (2018) Release of simple sugars from lignocellulosic biomass of Agave salmiana leaves subject to sequential pretreatment and enzymatic saccharification. Biomass and bioenergy 118:133-140.

Lemons e Silva, C.F., Artigas Schirmer, M., Nobuyuki Maeda, R., Araújo Barcelos, C., Pereira, N., (2015) Potential of giant reed (Arundo donax L.) for second generation ethanol production. Electronic Journal of Biotechnology 18:10-15.

Lemões, J.S., e Silva, C.F.L., Avila, S.P.F., Montero, C.R.S., e Silva, S.D.D.A., Samios, D., Peralba, M.D.C.R. (2018) Chemical pretreatment of Arundo donax L. for second-generation ethanol production. Electronic Journal of Biotechnology 31:67-74.

Menezes, E.G., do Carmo, J.R., Alves, J.G.L., Menezes, A.G., Guimarães, I.C., Queiroz, 


\section{Farkıı Seyreltik Sodyum Hidroksit Ön İşlem Metotlarının Kargı Kamışı (Arundo donax L.) Bitkisinden Fermente Olabilir Şeker ve Etanol Üretimine Etkileri}

F., Pimenta, C.J. (2014) Optimization of alkaline pretreatment of coffee pulp for production of bioethanol. Biotechnology progress 30:451-462.

Michalska, K., Bizukojć, M., Ledakowicz, S. (2015) Pretreatment of energy crops with sodium hydroxide and cellulolytic enzymes to increase biogas production. Biomass and Bioenergy 80: 213-221.

Miller, G.L., 1959. Use of dinitrosalicylic acid reagent for determination of reducing sugar. Anal. Chem. 31:426-428.

Nazlı, R. İ. (2017) Akdeniz iklim koşullarında bazı çok yıllık buğdaygillerin (miskantus, dallı darı, kargı kamıșı, yumrulu yem kanyaşı) enerji bitkisi olarak kullanım olanakları. Doktora Tezi. Çukurova Üniversitesi.

Nazli, R.I., Tansi, V., Öztürk, H.H., Kusvuran, A. (2018) Miscanthus, switchgrass, giant reed, and bulbous canary grass as potential bioenergy crops in a semiarid Mediterranean environment. Industrial Crops and Products 125:9-23.

Nazli, R.I. (2020) Evaluation of different sweet sorghum cultivars for bioethanol yield potential and bagasse combustion characteristics in a semiarid Mediterranean environment. Biomass and Bioenergy 139:105624.

Niemi, P., Pihlajaniemi, V., Rinne, M., Siikaaho, M. (2017) Production of sugars from grass silage after steam explosion or soaking in aqueous ammonia. Industrial Crops and Products 98: 93-99.

Nishimura, H., Kamiya, A., Nagata, T., Katahira, M., Watanabe, T. (2018) Direct evidence for $\alpha$ ether linkage between lignin and carbohydrates in wood cell walls. Scientific reports 8:111.

Pandey, A., Soccol, C.R., Nigam, P., Soccol, V.T. (2000) Biotechnological potential of agro-industrial residues. I: sugarcane bagasse. Bioresour. Technol 74:69-80.
Pesce, G.R., Fernandes, M. C., Mauromicale, G. (2020) Globe artichoke crop residues and their potential for bioethanol production by dilute acid hydrolysis. Biomass and Bioenergy 134:105471.

Phitsuwan, P., Sakka, K., Ratanakhanokchai, K. (2016) Structural changes and enzymatic response of Napier grass (Pennisetum purpureum) stem induced by alkaline pretreatment. Bioresource technology 218:247-256.

Rossa, B., Tuaers, A.V., Naidoo, G., Von Willert, D.J. (1998) Arundo donax L. (Poaceae) a C3 species with unusually high photosynthetic capacity. Botanica Acta, 111:216-221.

Qing, Q., Wyman, C.E. (2011) Supplementation with xylanase and $\beta$-xylosidase to reduce xylo-oligomer and xylan inhibition of enzymatic hydrolysis of cellulose and pretreated corn stover. Biotechnology for biofuels 4:1-12.

Santos, C.C., de Souza, W., Sant'Anna, C., Brienzo, M. (2018) Elephant grass leaves have lower recalcitrance to acid pretreatment than stems, with higher potential for ethanol production. Industrial Crops and Products 111:193-200.

Si, S., Chen, Y., Fan, C., Hu, H., Li, Y., Huang, J., Liao, H., Hao, B., Li, Q., Peng, L., Tu, Y., 2015. Lignin extraction distinctively enhances biomass enzymatic saccharification in hemicelluloses-rich Miscanthus species under various alkali and acid pretreatments. Bioresource technology 183:248-254.

Umagiliyage, A.L., Choudhary, R., Liang, Y., Haddock, J., Watson, D.G. (2015) Laboratory scale optimization of alkali pretreatment for improving enzymatic hydrolysis of sweet sorghum bagasse. Industrial Crops and Products 74:977-986.

Xu, J., Cheng, J.J., Sharma-Shivappa, R.R., Burns, J.C. (2010) Sodium hydroxide pretreatment of switchgrass for ethanol production. Energy \& Fuels 24:21132119. 


\section{Farklı Seyreltik Sodyum Hidroksit Ön İşlem Metotlarının Kargı Kamıșı (Arundo donax L.) Bitkisinden Fermente Olabilir Şeker ve Etanol Üretimine Etkileri}

Xu, J., Cheng, J.J. (2011) Pretreatment of switchgrass for sugar production with the combination of sodium hydroxide and lime. Bioresource technology 102:3861-3868.

Wang, Z., Keshwani, D.R., Redding, A.P., Cheng, J.J. (2010) Sodium hydroxide pretreatment and enzymatic hydrolysis of coastal Bermuda grass. Bioresource technology, 101:3583-3585.

Wang, Z., Li, R., Xu, J., Marita, J.M., Hatfield, R.D., Qu, R., Cheng, J. J. (2012) Sodium hydroxide pretreatment of genetically modified switchgrass for improved enzymatic release of sugars. Bioresource technology, 110:364-370.

Van Soest, P.J. (1963) Use of detergents in the analysis of fibrous feeds. 2. A rapid method for the determination of fiber and lignin. Journal of the Association of Official Agricultural Chemists 46:829-835.

Yan, X., Cheng, J.R., Wang, Y.T., Zhu, M.J. (2020) Enhanced lignin removal and enzymolysis efficiency of grass waste by hydrogen peroxide synergized dilute alkali pretreatment. Bioresource technology 301:122756.

Zhang, M., Wang, F., Su, R., Qi, W., He, Z. (2010) Ethanol production from high dry matter corncob using fed-batch simultaneous saccharification and fermentation after combined pretreatment. Bioresource Technology 101:4959-4964.

Zhu, S., Wu, Y., Yu, Z., Liao, J., Zhang, Y. (2005) Pretreatment by microwave/alkali of rice straw and its enzymic hydrolysis. Process Biochem. 40:3082-3086. 
Farklı Seyreltik Sodyum Hidroksit Ön İşlem Metotlarının Kargı Kamışı (Arundo donax L.) Bitkisinden Fermente Olabilir Şeker ve Etanol Üretimine Etkileri 